\title{
RECONSTRUCTING THE DOCTRINE OF THE SUFFICIENCY OF SCRIPTURE ${ }^{1}$
}

\section{Timothy Ward}

Although the doctrine of the sufficiency of Scripture has been a central doctrine in Protestant orthodox theology, it is, along with the general Reformation principle of sola Scriptura, and confessions of related attributes of Scripture (clarity, perfection and necessity), regularly treated superficially in both scholarly and popular contemporary writing. It is often rejected hastily, with little acknowledgement made of its fundamental place in Christian theology and belief both before and after the Reformation. It is often confessed unreflectively, without due recognition that it is a confession which must be argued for, and located carefully in relation to the fundamental trinitarian, christological and pneumatological doctrines of Christian theology.

This work aims to revisit the doctrine of the sufficiency of Scripture, offering a contemporary reconstruction of its theological, hermeneutical and philosophical bases. This brings the doctrine, especially in its orthodox Protestant formulation, into creative discussion with some related topics in contemporary theology, hermeneutics, literary theory and the philosophy of language. Material for the reconstruction is found especially in the basic concepts of speech-act theory, as they have been developed by J.L. Austin, John Searle and Nicholas Wolterstorff, and as applied to the Bible by Wolterstorff, Anthony Thiselton and Kevin Vanhoozer.

An introductory chapter outlines the academic contexts within which the content of the thesis is located: the interpretation of the historical doctrine of Scripture, especially that of the postReformation Protestant orthodox; the influence of linguistic and literary theory on contemporary theology and biblical studies; the question of authority in theology and how God is to be 'named'; the

1 Timothy Ward, Word and Supplement: Reconstructing the Doctrine of the Sufficiency of Scripture (Ph.D. thesis, University of Edinburgh, 1999); revised version, with amended subtitle, forthcoming from OUP; supervisor: Professor Kevin Vanhoozer. 
broad question of how Christian theology may think of God's action in light of modernity and post-modernity. A further academic context-Jacques Derrida's concept of the inevitable 'supplementation' of written texts-relates specifically to the overall title, Word and Supplement. Derrida's supplément is a concept aimed at revealing (by deconstructing) the radical insufficiency of any text. In addition, a variety of contemporary approaches to texts and theological views of Scripture can be described in terms of the 'supplement' which they provide, in order to account for how texts in general, and the Bible in particular, give rise to meaning. These include the author, the reader(s), the Holy Spirit, literary context, historical context—or none of these.

The body of the thesis begins with an analytical overview of the history of the development and decline of the doctrine of the sufficiency of Scripture, focusing on its full articulation in the Protestant Reformation and in post-Reformation Protestant scholasticism. Theologians of the latter period, particularly Francis Turretin, are defended against the charge that they departed significantly from the Reformation understanding of Scripture by developing a static and wooden doctrine of Scripture which tended to displace God, Christ and salvation from the theological and epistemological centre. The thesis as a whole requires this defence of the 'hard cases', since the sufficiency of Scripture was expressed most clearly by these writers. The detailed work of Richard Muller on the Reformed and of Robert Preus on the Lutherans of this period is offered as strong evidence that the differences between the theological writing of the Protestant orthodox and that of the Reformers are far more those of form rather than content. This analysis identifies three fundamental elements in the doctrine of the sufficiency of Scripture: the underlying theological claim that God speaks, and that Scripture is a medium of his speech; the material aspect-that Scripture contains everything that a person needs to know to be saved; the formal aspect-that the supreme authority in biblical interpretation is the Bible itself. After this historical introduction, the bulk of the thesis is given over to a reconstruction of each of these three elements in turn.

\section{Scripture and the Sufficiency of Divine Speech}

The reconstruction of the theological claim that God speaks in and through Scripture is approached via the basic conception of speechact theory, namely that to speak is fundamentally to act. Speech-act theorists call the basic aspect of speech the illocutionary act, which 
they distinguish conceptually from the acts of simply uttering words (the locutionary act) and bringing about in the hearer/reader the intended effect of one's words (the perlocutionary act). Although there are debates between speech-act theorists, and their work is regularly criticised, these fundamental distinctions can be shown both to be commonly asserted by several viewpoints with linguistics and the philosophy of language, and to be philosophically legitimate. Wolterstorff has developed this work, arguing that speech-as-action is fundamentally an ethical activity: by speaking we establish and sustain ethical, inter-subjective relations.

This construal of language is used to inform a reading of Karl Barth's particular conception of God as speaking 'literally' in and through the Bible, in order to assess his rejection of fundamental aspects of the classical Protestant doctrine of Scripture. In asserting that God is a speaking God, Barth intended to safeguard God's freedom, as Lord of Scripture, to act in and through Scripture over against humanity. He argued that any direct identification of the Bible with divine revelation makes God a predicate of a human text, thus compromising his freedom as God. This of course, as Hans Frei once pointed out, is in line with the basic concepts of speech-act theory. We may agree with Barth's fundamental concerns, but also argue that in reading Scripture, directly identified as God's act, we do not necessarily come to possess God, exerting our freedom over his; rather, we are ethically bound to submit ourselves to his action on and in us, exercised in and through the text. God can be trusted as our Lord, in and through Scripture, because he promises to serve us by being present to us as a speaking/acting God in our Bible-reading.

\section{Scripture and the Sufficiency of the Text}

The material aspect of the sufficiency of Scripture declares that Scripture contains everything necessary to be known for salvation; the reconstruction of this doctrine entails a treatment of the fundamental question of textual ontology. Various models of textual ontology are analysed, in terms of the 'supplement' which each offers (or does not offer) in order to account for textual meaning. These are: the models of 'textual self-sufficiency' offered in literary theory by New Criticism and in theology by Hans Frei; the opposing construals of authorship developed by E.D. Hirsch and deconstruction, especially as the latter is exemplified in the work of the NT scholar Stephen Moore; the various reader- and community-oriented hermeneutics 
offered by the philosopher Hans-Georg Gadamer, the literary theorist Stanley Fish and the theologian Stanley Hauerwas.

In light of these discussions, it is argued that a careful articulation of the sufficiency of Scripture requires ethical descriptions of the relationships between both authors and textual meaning and readers and textual meaning; the sufficiency of Scripture is therefore not a 'self-sufficiency' of the text. Scripture is materially sufficient for the performance of the divine illocutionary act of calling us to trust Christ for salvation. This active divine 'semantic presence' becomes divine 'personal presence' through the perlocutionary action of the Holy Spirit in us.

\section{Scripture and the Sufficiency of the Canon}

The formal aspect of the sufficiency of Scripture, which claims that Scripture is sufficient for its own interpretation, is an argument for a kind of 'intertextual' reading of Scripture as a thematically and chronologically diverse set of texts. Rather than looking to the poststructuralist theories of intertextuality of Julia Kristeva and Roland Barthes, helpful philosophical resources are found in the work of Mikhail Bakhtin on language, who argues that language is irreducibly polyphonic (Bakhtin's term is 'heteroglossic'). Paul Ricoeur's work on the literary genres of the Bible, in which he argues that the referent "God" 'expresses the circulation of meaning' between the Bible's different texts, is a Christian example of Bakhtin's general point. Richard Hays' work on Paul's use of the OT provides exegetical examples of this. This gives rise to a conception of the canon as an unsystematic polyphony.

Within biblical studies, B.S. Childs' attempts at a canonical approach to Scripture turn out, on analysis, to require precisely the strong account of biblical inspiration, in order to mark out the uniqueness of the canon, which Childs himself rejects. B.B. Warfield's account of biblical inspiration (another hard case!) is therefore discussed. Many contemporary critics of Warfield, it is argued, misrepresent his position; although his terminology does seem to flatten Scripture out as a series of 'oracles' from God, his basic concepts and exegetical practice are usually sensitive to the polyphonic ways in which 'what Scripture says, God says'. The canon of Scripture, it is then argued, is to be conceived of as sufficient for the continued performance of the illocutionary act which God once performed in the preparation for, in the witness back to, and in the actuality of, his self-revelation in the Word made flesh. 
A faithful formulation of the doctrine of the sufficiency of Scripture does not claim to guarantee faithful belief and practice; rather, by confessing the doctrine the church acknowledges the 'supplement' it always needs from beyond itself, as God speaks to us in and through a Scripture which we never fully possess. 